\title{
Analisis Kesiapan Modernisasi Daerah Irigasi Kedung Putri pada Tingkat Sekunder Menggunakan Metode K-Medoids Clustering
}

\author{
Modernization Readiness Analysis of Kedung Putri Irrigation System at Secondary Level Using K-Medoids \\ Clustering Method
}

\author{
Ansita Gupitakingkin Pradipta*, Anditya Sridamar Pratyasta, Sigit Supadmo Arif \\ Departemen Teknik Pertanian dan Biosistem, Fakultas Teknologi Pertanian, \\ Universitas Gadjah Mada, Jl. Flora No. 1, Bulaksumur, Yogyakarta 55281, Indonesia \\ *Email: ansita.pradipta@ugm.ac.id
}

Tanggal submisi: 16 November 2018; Tanggal penerimaan: 20 Februari 2019

\begin{abstract}
ABSTRAK
Persiapan modernisasi Daerah Irigasi (DI) Kedung Putri memerlukan penilaian menyeluruh pada pilar-pilar irigasi, salah satunya pada tingkat sekunder. Untuk memudahkan dalam penilaian dan rencana pengembangan, dilakukan suatu clustering dengan metode k-medoids yang menggunakan suatu data representatif (medoid) sebagai pusat cluster. Selanjutnya dilakukan pengambilan keputusan dengan metode Analytic Hierarchy Process (AHP). Penilaian kinerja 21 saluran sekunder dinyatakan dalam indeks kesiapan modernisasi irigasi (IKMI). Hasil penilaian menunjukkan bahwa 9,52\% termasuk dalam kriteria baik, 71,43\% termasuk dalam kriteria cukup, dan $19,05 \%$ termasuk dalam kriteria kurang. Berdasarkan hasil tersebut tampak bahwa DI Kedung Putri belum siap untuk modernisasi. Untuk itu, terlebih dahulu perlu dilakukan penyempurnaan sistem secara berkelompok, yaitu dengan pengelompokan berdasarkan kemiripan (clustering). Metode yang digunakan yaitu k-medoids clustering menggunakan software Rapid Miner 9.0. Hasil clustering menunjukkan bahwa jumlah cluster paling optimal adalah 4 cluster, dengan nilai Davies Bouldin Index (DBI) -1,959. Anggota cluster 0, 1, 2, dan 3 berturut-turut adalah $6,6,8$, dan 1 saluran sekunder. Selanjutnya diperlukan penyusunan skala prioritas pengembangan cluster berdasarkan kinerja pilar-pilar irigasi pada saluran sekunder. Hasil analisis AHP menunjukkan bahwa urutan prioritas pengembangan dimulai dari cluster 0 , diikuti dengan cluster 2,1 , dan 3 . Rekomendasi pengembangan saluran sekunder yang tergabung pada cluster 0 antara lain dengan peningkatan pasokan air, pemeliharaan rutin prasarana, pendampingan teknis, dan kampanye publik dalam pengelolaan irigasi. Saluran sekunder yang tergabung pada cluster 3 memiliki kinerja baik pada seluruh pilar, sehingga hanya perlu mempertahankan pola operasi dan pemeliharaan yang ada.
\end{abstract}

Kata kunci: Analytic hierarchy process; k-medoids clustering; rapid miner; indeks kesiapan modernisasi irigasi

\begin{abstract}
Preparation for the modernization of the Kedung Putri Irrigation System (DI Kedung Putri) required a comprehensive assessment of the irrigation pillars, one of which was at the secondary level. To facilitate the assessment and development plan, a clustering was carried out using the k-medoids method, that used a representative data (called medoid) as the cluster center. Then, decision making was conducted by using the Analytic Hierarchy Process (AHP) method. The performance assessment of 21 secondary channels was stated as the readiness index of irrigation modernization (IKMI). The assessment result showed that $9.52 \%$ belonged to good criteria, $71.43 \%$ belonged to fair criteria, and $19.05 \%$ belonged to poor criteria. Based on these results that DI Kedung Putri was considered not ready yet to be modernized. For this reason, it was necessary to conduct the system improvement in groups, namely by grouping based on similarities (clustering). The used method was k-medoids
\end{abstract}


clustering using Rapid Miner 9.0 software. The clustering result showed that the optimal cluster number was 4 clusters, with the Davies Bouldin Index (DBI) value -1.959. The members of the 0,1, 2 and 3 clusters were 6, 6,8 and 1 secondary channels, respectively. Furthermore, a priority scale in clusters development was needed based on the performance of irrigation pillars on secondary channels. The results of AHP analysis showed that the order of priority development starts from cluster 0 , followed by cluster 2, 1 and 3 . The recommendations for the development of secondary channels incorporated in cluster 0 , such as increasing water supply, routine infrastructure maintenance, technical assistance, and public campaigns in irrigation management. The secondary channels incorporated in cluster 3 had good performance on all pillars, so it only needed to maintain the existing operation and maintenance patterns.

Keywords: Analytic hierarchy process; k-medoids clustering; rapid miner; readiness index of irrigation modernization

\section{PENDAHULUAN}

Modernisasi irigasi merupakan upaya mewujudkan sistem pengelolaan irigasi partisipasif yang berorientasi pada pemenuhan tingkat layanan irigasi secara efektif, efisien, dan berkelanjutan, dalam rangka mendukung ketahanan pangan danair, melaluipeningkatan keandalan penyediaan air, prasarana, pengelolaan irigasi, institusi pengelola, dan sumber daya manusia (Anonim, 2011). Modernisasi adalah proses berkelanjutan yang dilakukan secara bertahap. Diperlukan suatu langkah awal untuk menilai kesiapan daerah irigasi dalam perencanaan modernisasi irigasi. Kesiapan ini dinyatakan dengan Indeks Kesiapan Modernisasi Irigasi (IKMI), yang dapat digunakan untuk merumuskan strategi selanjutnya (Anonim, 2011).

Penilaian IKMI perlu segera dilakukan, terutama pada daerah irigasi besar yang menjadi kewenangan dan tanggung jawab pemerintah pusat. Salah satunya adalah Daerah Irigasi (DI) Kedung Putri yang terletak di Kabupaten Purworejo, dengan luas layanan $4.341 \mathrm{Ha}$. Harapannya dapat segera dilakukan pengambilan keputusan apakah siap dilakukan perencanaan modernisasi irigasi atau diperlukan suatu penyempurnaan sistem terlebih dahulu. Perencanaan modernisasi ini akan lebih efisien jika dilakukan secara berkelompok. Salah satu cara yang dapat dilakukan adalah dengan mengelompokkan suatu obyek dari sistem irigasi berdasarkan pada kemiripan kinerja pilar-pilar irigasi, pengelompokan ini disebut dengan clustering (Pramesti dkk., 2017).

Salah satu metode clustering yang dapat digunakan adalah k-medoids, yang menggunakan suatu obyek representatif sebagai pusat cluster. Pusat cluster ini kemudian disebut dengan medoid (Kaur dkk., 2014). Keunggulan dari metode ini adalah kekuatannya, yaitu tidak terpengaruh terhadap adanya data outliers ataupun data ekstrem (Bhat, 2014).
Nugraha (2018) telah melakukan penelitian serupa yaitu mengelompokkan dan memetakan Perkumpulan Petani Pemakai Air (P3A) pada DI Serayu berdasarkan nilai IKMI menggunakan metode fuzzy c-means. Penelitian yang dilakukan hanya berhenti pada clustering P3A, yang dalam hal ini mewakili kinerja sistem irigasi di tingkat tersier. Penelitian tersebut dapat dikembangkan dengan perumusan pengambilan keputusan berdasarkan hasil clustering. Pengambilan keputusan tersebut dapat disusun ke dalam skala prioritas penanganan cluster, selanjutnya dirumuskan rekomendasi yang sesuai. Salah satu metode pengambilan keputusan yang dapat digunakan adalah Analytic Hierarchy Process (AHP). Metode ini merupakan suatu model secara komprehensif karena memiliki kemampuan menyelesaikan masalah dengan multi kriteria (Mulyadi dkk., 2014). Pengambilan keputusan yang melibatkan banyak kriteria (multi kriteria) dan subkriteria digunakan untuk menentukan peringkat alternatif keputusan (Saaty, 2008). Kriteria dalam hal ini merupakan 5 pilar irigasi, yaitu ketersediaan air, prasarana, sistem pengelolaan, institusi pengelola, dan sumber daya manusia (SDM).

Penelitian ini bertujuan untuk menilai kesiapan modernisasi irigasi DI Kedung Putri pada tingkat sekunder, yaitu dengan melakukan penilaian 5 pilar irigasi yang dituangkan dalam IKMI. Selanjutnya dilakukan penyusunan skala prioritas rencana pengembangan pada tingkat sekunder, yang dilakukan secara berkelompok dalam suatu clustering. Penyusunan skala prioritas ini menggunakan metode Analytic Hierarchy Process (AHP).

\section{METODE PENELITIAN}

\section{Lokasi Penelitian}

Penelitian ini dilakukan pada DI Kedung Putri yang terletak di Kabupaten Purworejo, Provinsi Jawa Tengah. DI Kedung Putri mengairi lahan persawahan seluas 3.431 
Ha. Berdasarkan Peraturan Menteri Pekerjaan Umum dan Perumahan Rakyat (PUPR) RI Nomor 14/PRT/M/2015, pengembangan dan pengelolaan sistem irigasi pada DI dengan luas lebih dari 3.000 Ha merupakan wewenang dan tanggung jawab dari pemerintah pusat. Dalam hal ini, instansi yang berwenang adalah adalah Balai Besar Wilayah Sungai (BBWS) Serayu Opak yang berada di bawah naungan Direktorat Jenderal Sumber Daya Air, Kementerian Pekerjaan Umum dan Perumahan Rakyat. Dalam pelaksanaan tugas pengelolaan DI Kedung Putri, BBWS Serayu Opak bekerjasama dengan institusi di tingkat provinsi dan kabupaten. Institusi tingkat provinsi yang terlibat dalam pengelolaan DI Kedung Putri adalah Balai Pekerjaan Umum Sumber Daya Air dan Penataan Ruang Progo Bogowonto Luk Ulo (BPUSDATARU Probolo), yang berada di bawah naungan Pemerintah Provinsi Jawa Tengah. Pelaksana teknis tingkat kabupaten diwakili oleh Unit Pelaksana Teknis Daerah (UPTD) Wilayah Purworejo, yang berada di bawah naungan Dinas Pekerjaan Umum dan Penataan Ruang (DPUPR) Kabupaten Purworejo. Pasokan air DI Kedung Putri berasal dari Sungai Bogowonto melalui Bendung Kedung Putri, terletak pada koordinat $110^{\circ} 02^{\prime} 12,86^{\prime \prime}$ BT dan $7^{\circ} 41^{\prime} 12,1^{\prime \prime}$.

\section{Pengumpulan dan Pengolahan Data}

Pengumpulan data dilakukan dengan dua metode, yaitu penelusuran jaringan irigasi (PJI) untuk pilar prasarana, dan wawancara menggunakan tool kuisioner untuk 4 pilar lainnya. PJI dilakukan untuk mengetahui persentase panjang saluran dengan kondisi baik terhadap panjang saluran saluran total. Hal ini digunakan sebagai penilaian terhadap pilar prasarana.

Penilaian 4 pilar selain prasarana, yaitu pilar ketersediaan air, sistem pengelolaan, institusi pengelola, dan sumber daya manusia (SDM) menggunakan kuisioner. Formulir kuisioner yang digunakan mengacu pada panduan modernisasi irigasi yang dikeluarkan oleh Kementerian Pekerjaan Umum (Anonim, 2011). Secara keseluruhan responden dalam wawancara untukpenilaian kesiapan modernisasi irigasi adalah dari pihak Balai Besar Wilayah Sungai (BBWS), Dinas Pekerjaan Umum tingkat kabupaten, kantor bendung, Unit Pelaksana Teknis Daerah (UPTD), Gabungan Perkumpulan Petani Pemakai Air (GP3A), dan P3A. Jumlah pertanyaan secara keseluruhan adalah 56 yang mencakup 4 pilar irigasi. Masing-masing pertanyaan mewakili pilar tertentu dan memiliki bobot tertentu. Bobot pertanyaan ini mengacu pada panduan modernisasi irigasi (Anonim, 2011). Dari 56 pertanyaan tersebut jika dijumlahkan akan diperoleh bobot total pertanyaan adalah 400 (terdiri dari 4 pilar dan masing-masing pilar mempunyai bobot total 100).

Dalam penelitian ini hanya menggunakan responden P3A. Dipilih sampel 39 responden P3A yang mewakili pengguna air di 21 saluran sekunder. Formulir kuisioner yang ditujukan untuk reponden P3A terdiri dari 10 pertanyaan yang mencakup 4 pilar irigasi (Tabel 1). Penilaian menggunakan skala $1-5$ yang merupakan representasi jawaban wawancara dari tiap responden terhadap pertanyaan yang diajukan.

Tabel 1. Daftar pertanyaan pada kuisioner beserta nilai bobot

\begin{tabular}{lccl}
\hline Pilar & Nilai bobot & No pertanyaan & Pertanyaan \\
\hline Ketersediaan air & 33,3 & 1 & $\begin{array}{l}\text { Ketersediaan air di petak tersier } \\
\text { Ketercukupan untuk memenuhi target IP yang } \\
\text { ditentukan } \\
\text { Kaitan pola tanam dalam memenuhi target IP yang } \\
\text { ditentukan }\end{array}$ \\
Institusi pengelola & 8,30 & 3 & $\begin{array}{l}\text { Distribusi air di tingkat tersier } \\
\text { Kelembagaan P3A }\end{array}$ \\
& 12,12 & 5 & $\begin{array}{l}\text { Kapasitas dan peran P3A dalam partisipasi } \\
\text { pengembangan dan pengelolan irigasi di tingkat } \\
\text { tersier sebagai pemanfaat (user) }\end{array}$ \\
Sumber daya manusia & 40,00 & 7 & $\begin{array}{l}\text { Jumlah petani sekaligus pemilik sawah dibandingkan } \\
\text { dengan jumlah petani yang ada } \\
\text { Tingkat partisipasi anggota dalam lembaga P3A } \\
\text { Jumlah petani yang membayar iuran ke P3A } \\
\text { dibandingkan dengan jumlah petani yang ada } \\
\text { Presentase petani yang memiliki lahan lebih dari } 2 \text { Ha }\end{array}$ \\
\hline
\end{tabular}


Selanjutnya dilakukan rekapitulasi penilaian dengan kuisioner. Data dari 39 responden P3A dikelompokkan berdasarkan saluran sekunder yang diwakili. Satu saluran sekunder dapat terdiri dari beberapa data. Kemudian data tersebut dirata-ratakan nilainya, sehingga diperoleh penilaian terhadap 21 saluran sekunder pada 4 pilar irigasi dengan skala 1-5. Data penilaian pilar prasarana (skala 0-100\%) yang diperoleh dari PJI digabungkan, sehingga diperoleh rekapitulasi penilaian pada 5 pilar irigasi.

Penilaian pada 4 pilar dikalikan dengan bobot pertanyaan pada Tabel 1 . Kemudian seluruh penilaian 5 pilar dikalikan dengan bobot utama pilar, yang menunjukkan tingkat kepentingan pilar dalam suatu sistem irigasi. Bobot utama pilar tersebut adalah 20\% untuk pilar ketersediaan air, 25\% untuk pilar prasarana, $15 \%$ untuk pilar sistem pengelolaan, $20 \%$ untuk pilar institusi pengelola, dan 20\% untuk pilar SDM. Hasil penilaian yang telah terbobot dijumlahkan untuk memperoleh nilai IKMI tiap saluran sekunder. Nilai IKMI ini dapat diklasifikasikan ke dalam beberapa kategori yaitu jika nilai $>80$ maka termasuk kategori baik, berarti modernisasi dapat langsung diterapkan; jika nilai 50-80 maka termasuk kategori cukup, berarti modernisasi ditunda dan perlu dilakukan penyempurnaan sistem irigasi 1-2 tahun; jika nilai $<50$ maka termasuk kategori kurang, berarti modernisasi ditunda dan perlu dilakukan penyempurnaan sistem irigasi 2-4 tahun; serta jika nilai <30 maka termasuk kategori sangat kurang, berarti modernisasi tidak perlu dilakukan pada daerah tersebut, atau dilakukan penyempurnaan yang fundamental (Anonim, 2011).

\section{Clustering}

Terkait rencana pengembangan saluran sekunder, akan lebih efisien jika dilakukan secara berkelompok. Untuk itu, maka dilakukan pengelompokan berdasarkan kemiripan kinerja saluran sekunder (clustering). Sebelum dilakukan clustering, data penilaian terbobot dinormalisasi untuk menyetarakan rentang penilaian. Selain itu, normalisasi dilakukan supaya nilai menjadi terskala pada jangkauan kecil dan spesifik seperti 0,0 ke 0,1 (Jain dan Bhandare, 2011). Metode normalisasi data secara umum dapat dilakukan dengan beberapa cara, untuk penelitan ini menggunakan metode normalisasi min-max. Metode ini menskala data dari nilai $d$ menjadi $d^{\prime}$ dalam jangkauan data minimum $(p)$ hingga maksimum $(p)$, sebagaimana Persamaan 1 (Jain dan Bhandare, 2011).

$$
d^{\prime}=\frac{d-\min (p)}{\max (p)-\min (p)}
$$

dimana:

$d^{\prime} \quad:$ data ternormaliasi

d : data awal

$\min (p)$ : data minimum pada suatu atribut

$\max (p)$ : data maksimum pada suatu atibut.

\section{K-Medoids Clustering Method}

Salah satu metode clustering adalah dengan partisi. Metode pemartisian yang paling terkenal dan biasa digunakan adalah k-means, k-medoids dan variasivariasinya (Han, dkk., 2001). K-Medoids atau Partitioning Around Medoid (PAM) adalah metode clustering yang dikembangkan oleh Kaufman dan Rosseeuw, sebagai alternatif yang lebih baik dari k-means (Soni dan Patel, 2017). Metode k-medoids tidak sensitif terhadap data outliers dan cukup efisien untuk dataset yang kecil. Langkah awal k-medoids adalah mencari titik yang paling representatif (medoids) dalam sebuah dataset, dengan menghitung jarak dalam kelompok dari semua kemungkinan kombinasi dari medoids, sehingga jarak antar titik dalam suatu cluster kecil, sedangkan jarak titik antar cluster besar (Han dkk., 2001). Jarak antar titik ini menggunakan persamaan eucledian distance (2) (Pramesti dkk., 2017).

$$
d(x, y)=\sqrt{\sum_{i=1}^{n}\left|x_{i}-y_{i}\right|^{2}}
$$

dimana:

$d(x, y):$ jarak antara data ke $-i$ dan data $\mathrm{ke}-j$

$x_{i} \quad$ : nilai atribut dari data $\mathrm{ke}-i$

$y_{i} \quad:$ nilai atribut dari data ke $-j$

$n \quad:$ jumlah atribut yang digunakan

Proses dalam k-medoids clustering dapat dituangkan ke dalam suatu algoritma seperti ditunjukkan pada Gambar 1.

Metode k-medoids clustering menuntut pengguna untuk menentukan sendiri jumlah $k$ cluster. Untuk menguji optimalisasi jumlah cluster yang ditentukan, digunakan parameter Davies Bouldin Index (DBI) dengan Persamaan 3 sampai dengan 6 (Adiana, dkk., 2018).

$$
\begin{aligned}
D B I & =\frac{1}{k}+\sum_{i=1}^{k} \max _{i \neq j}\left(R_{i, j}\right) \\
R_{i, j} & =\frac{S S W_{i}+S S W_{i}}{S S B_{i, j}}
\end{aligned}
$$




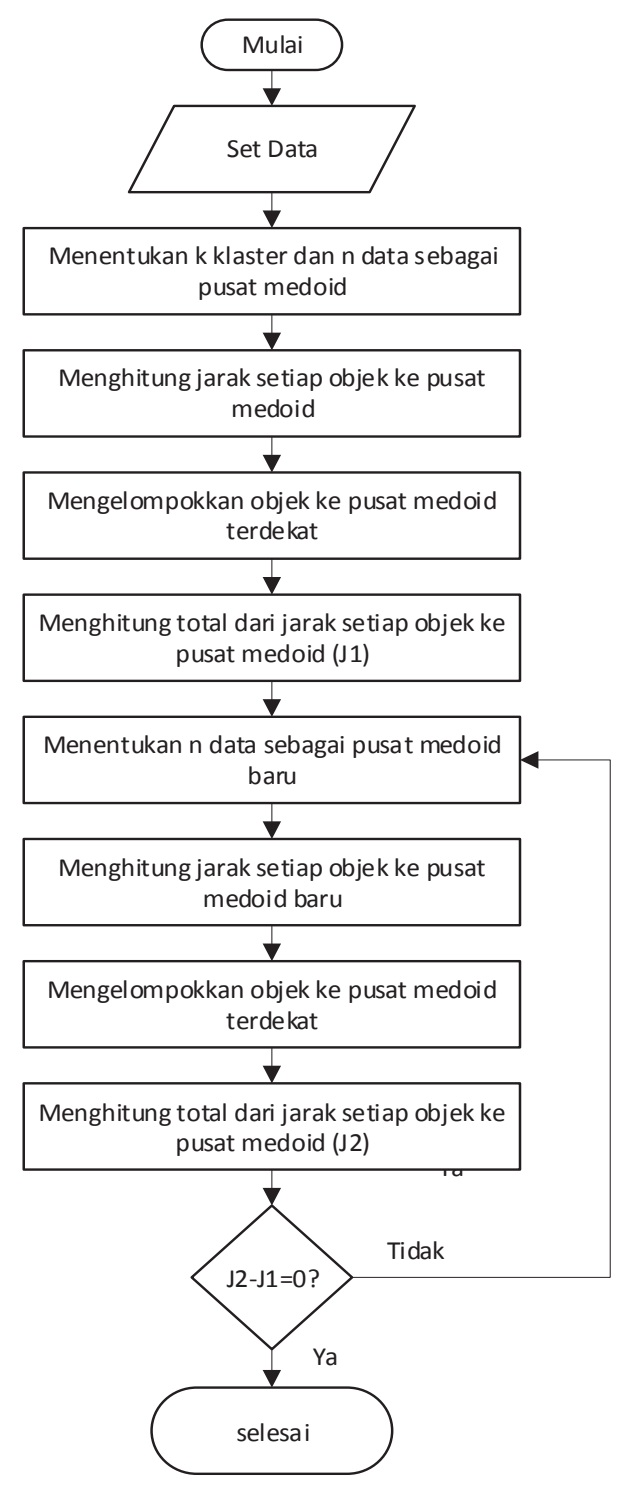

Gambar 1. Flowchart Algoritma K-Medoid Clustering

$$
\begin{aligned}
& S S B_{i, j}=d\left(c_{i}, c_{j}\right) \\
& S S W=\frac{1}{m_{i}}+\sum_{j=1}^{m_{i}} d\left(X_{j}, C_{i}\right)
\end{aligned}
$$

\section{Analytic Hierarchy Process (AHP)}

Menurut Saaty (2008) Analytic Hierarchy Process (AHP) adalah teori pengukuran melalui perbandingan berpasangan (pairwise comparisons) dan bergantung pada penilaian para ahli untuk memperoleh skala prioritas. Skala yang dimaksud digunakan untuk mengukur hal yang tidak berwujud (intangibles) secara relatif. AHP adalah metode yang sistematik untuk membandingkan sejumlah sasaran ataupun alternatif, karena struktur logikanya jelas. AHP memberikan suatu dasar pendekatan dalam pengambilan keputusan secara rasional dan intuitif untuk memperoleh yang terbaik dari sejumlah alternatif yang dievaluasi dengan multi kriteria (Mulyadi dkk., 2014).

AHP telah digunakan untuk membantu banyak pembuat keputusan perusahaan dan pemerintah. Bagian penting dari proses AHP ini adalah menyelesaikan tiga langkah, yaitu menyatakan tujuan, menentukan kriteria, dan memilih seluruh alternatif. Informasi tersebut kemudian disusun dalam suatu bagan hirarki. Informasi tersebut kemudian disintesis untuk menentukan peringkat relatif dari alternatif (Haas dan Meixner, 2005).

Pemilihan alternatif diawali dengan pembandingan antar elemen. Terdapat dua cara pembandingan antara lain pembandingan absolut (scoring) yaitu pembandingan terhadap standar tertentu, dan pembandingan relatif (scalling) yaitu membandingkan antar pasangan elemen sehingga disebut pula dengan pembandingan berpasangan (pairwise comparison) (Murtiningrum, dkk., 2007).

Langkah pertama dalam AHP yaitu menyusun suatu bagan hirarki yang berisi tujuan yang ingin dicapai, kriteria, dan alternatif yang akan dipilih. Dalam penelitian ini tujuan yang ingin dicapai adalah pemilihan cluster dengan kondisi terbaik, sehingga diperoleh urutan skala prioritas penanganan cluster dari yang terburuk. Kriteria yang ditentukan adalah 5 pilar irigasi dengan alternatif clusters yang terbentuk.

\section{HASIL DAN PEMBAHASAN}

\section{Penilaian Kinerja Saluran Sekunder}

Hasil penilaian IKMI saluran sekunder pada DI Kedung Putri disajikan pada Tabel 2. Kategori pada kolom terakhir mengacu pada bagian pengumpulan dan pengolahan hasil.

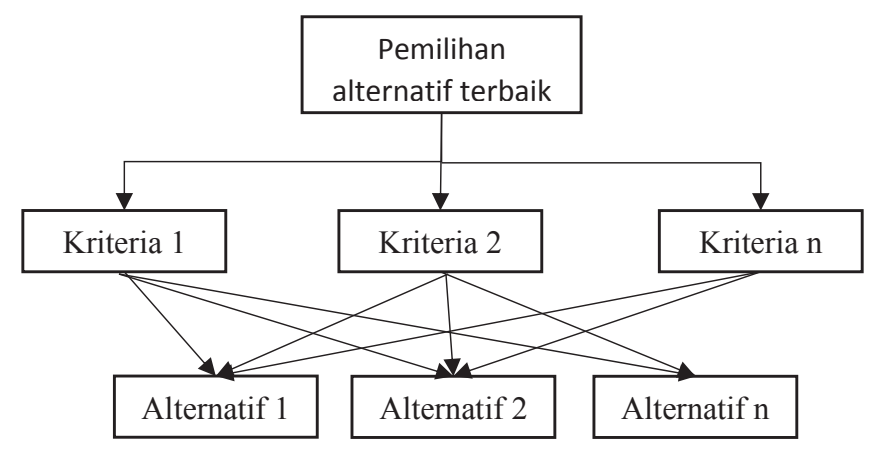

Gambar 2. Bagan hirarki AHP 
Tabel 2. Penilaian IKMI saluran sekunder DI Kedung Putri

\begin{tabular}{|c|c|c|c|c|c|c|c|}
\hline \multirow[b]{2}{*}{ Nama saluran sekunder } & \multicolumn{5}{|c|}{ Pilar Irigasi } & \multirow{2}{*}{$\begin{array}{c}\text { Total } \\
\text { (IKMI) }\end{array}$} & \multirow[b]{2}{*}{ Kategori } \\
\hline & Ketersediaan air & Prasarana & $\begin{array}{c}\text { Sistem } \\
\text { pengelolaan }\end{array}$ & $\begin{array}{c}\text { Institusi } \\
\text { pengelola }\end{array}$ & SDM & & \\
\hline Baledono hewan & 6,15 & 49,99 & 2,12 & 3,36 & 8,61 & 70,23 & Cukup \\
\hline Pabrik es & 9,23 & 49,03 & 2,79 & 5,03 & 10,61 & 76,69 & Cukup \\
\hline Plaosan & 9,23 & 9,61 & 2,50 & 3,36 & 9,23 & 33,93 & Kurang \\
\hline Kauman & 9,23 & 11,54 & 2,16 & 2,94 & 9,00 & 34,86 & Kurang \\
\hline Sindurjan & 13,84 & 21,25 & 2,50 & 3,36 & 9,69 & 50,64 & Cukup \\
\hline Doplang & 12,31 & 23,33 & 2,40 & 3,08 & 9,23 & 50,34 & Cukup \\
\hline Tirem & 13,84 & 21,20 & 2,26 & 4,06 & 10,61 & 51,97 & Cukup \\
\hline Legundi & 12,31 & 19,23 & 2,69 & 3,36 & 9,23 & 46,81 & Kurang \\
\hline Koplak & 10,77 & 27,37 & 2,60 & 3,36 & 9,23 & 53,32 & Cukup \\
\hline Pleret & 15,38 & 0,00 & 2,50 & 5,03 & 11,07 & 33,99 & Kurang \\
\hline Kenteng Grantung & 12,31 & 39,28 & 2,69 & 1,12 & 11,07 & 66,47 & Cukup \\
\hline Kenteng Dewi & 11,28 & 29,76 & 1,86 & 3,92 & 10,15 & 56,97 & Cukup \\
\hline Wongsokrasan & 9,23 & 57,68 & 2,31 & 1,68 & 8,31 & 79,20 & Cukup \\
\hline Tegal Kuning & 6,15 & 52,31 & 2,50 & 5,03 & 10,15 & 76,15 & Cukup \\
\hline Tegal Liser & 6,15 & 55,46 & 0,77 & 3,92 & 10,15 & 76,45 & Cukup \\
\hline Seboro Krapyak & 10,77 & 32,43 & 1,25 & 3,92 & 9,69 & 58,05 & Cukup \\
\hline Korok Alas Tengah & 11,28 & 43,72 & 2,05 & 4,10 & 9,54 & 70,69 & Cukup \\
\hline Kesambi Plenden & 10,46 & 50,87 & 2,12 & 3,69 & 11,26 & 78,39 & Cukup \\
\hline Bloro Buduk & 15,38 & 23,03 & 2,31 & 4,20 & 11,54 & 56,45 & Cukup \\
\hline Kembar Kleren & 15,38 & 53,84 & 2,69 & 4,47 & 15,69 & 92,07 & Baik \\
\hline Pangen Mangunan & 9,23 & 55,99 & 1,70 & 3,73 & 9,84 & 80,49 & Baik \\
\hline Standar Deviasi & 2,88 & 17,62 & 0,50 & 0,97 & 1,54 & 16,81 & \\
\hline
\end{tabular}

Berdasarkan Tabel 2, terdapat 2 saluran sekunder $(9,52 \%)$ termasuk kriteria baik yang berarti siap dilakukan modernisasi, 15 saluran sekunder $(71,43 \%)$ termasuk kriteria cukup yang berarti perlu dilakukan penyempurnaan sistem selama 1-2 tahun, dan 4 saluran sekunder $(19,05 \%)$ termasuk kriteria kurang yang berarti perlu dilakukan penyempurnaan sistem selama 2-4 tahun. Saluran sekunder dengan kinerja terbaik adalah Kembar Kleren dengan nilai IKMI 92,07, sedangkan kinerja terburuk adalah Pleret dengan nilai IKMI 33,99. Oleh sebab itu secara keseluruhan DI Kedung Putri pada tingkat sekunder belum siap dilakukan modernisasi irigasi. Perlu dilakukan upaya perbaikan dan penyempurnaan sistem terlebih dahulu. Untuk memudahkan dalam pengembangan nantinya, dilakukan suatu pengelompokan berdasarkan kemiripan kondisi kinerja (clustering).

\section{Pengelompokan (Clustering) Saluran Sekunder}

Proses clustering kinerja saluran sekunder dilakukan dengan bantuan Software Rapid Miner 9.0, dengan algoritma k-medoids clustering. Masukan dalam clustering adalah data kinerja saluran sekunder terbobot yang telah dinormalisasi. Data kinerja tersebut terdiri dari 6 atribut, yaitu 1 atribut berupa nama saluran sekunder dan 5 atribut berupa 5 pilar irigasi. Untuk keperluan uji, atribut nama saluran sekunder perlu dirubah tipenya menjadi atribut label. Hal ini dilakukan karena atribut nama saluran merupakan target dari proses clustering yang dilakukan. Pengubahan tipe atribut tersebut dilakukan dengan bantuan operator set role yang tersedia di dalam Rapid Miner 9.0.

Tahapan clustering dengan Rapid Miner 9.0 disajikan pada Gambar 3. Setelah data masuk ke 


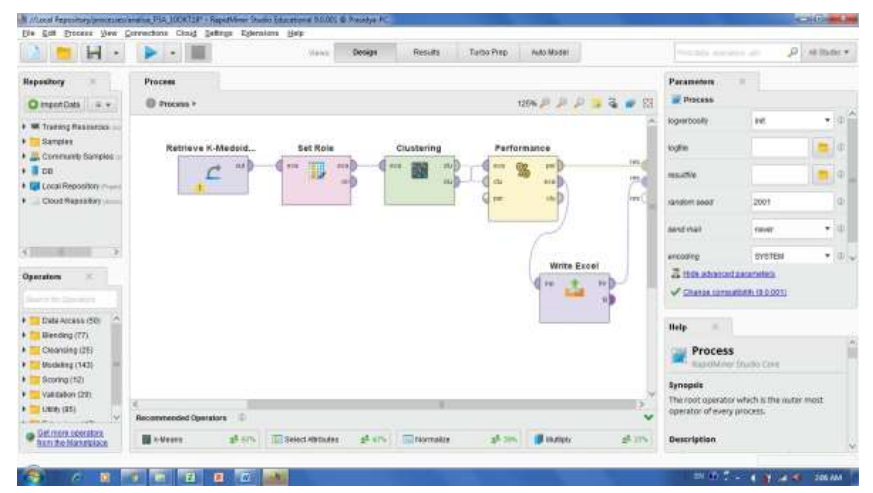

Gambar 3. Tahapan proses clustering dengan Rapid Miner 9.0.

operator set role, kemudian data masuk ke operator clustering. Selanjutnya data hasil clustering perlu diuji keandalannya dengan menggunakan operator cluster distance performance. Hal ini dilakukan karena algoritma k-medoids melibatkan perhitungan jarak obyek ke obyek lain. Data hasil clustering masuk ke operator write Excel guna disimpan pada direktori yang ditentukan dengan ekstensi .xls. Output yang diperoleh berupa nilai pusat cluster (centroid) dan keanggotaan cluster (cluster membership). Khusus untuk metode clustering k-medoids nama centroid disebut dengan medoid. Nilai medoid merepresentasikan kondisi tiap cluster berdasarkan atribut-atributnya, dalam hal ini 5 pilar irigasi.

Algoritma k-medoids menuntut user untuk menentukan sendiri jumlah $k$ cluster pada awal proses. Pada penelitian ini dilakukan trial jumlah cluster dari 2 hingga 10, kemudian ditentukan jumlah cluster yang paling optimal berdasarkan nilai Davies Boouldin Index (DBI). Menurut (Adiana dkk., 2018) dan (Hardiani, dkk., 2017) semakin rendah nilai DBI, maka semakin optimal jumlah cluster yang terbentuk. Dari hasil trial jumlah cluster diperoleh nilai DBI paling rendah terdapat pada jumlah 4 cluster, yaitu dengan nilai $-1,959$. Nilai DBI jumlah cluster lainnya dapat dilihat pada Tabel 3. Dengan hasil ini maka digunakan jumlah 4 cluster yang terdiri dari cluster $0,1,2$ dan cluster 3 dengan nilai medoid tiap pilar disajikan pada Gambar 4. Tiap cluster memiliki jumlah keanggotaan yang bervariasi. Cluster $0,1,2$, dan 3 berturut-turut memiliki anggota 6, 6, 8, dan 1 saluran sekunder. Keanggotaan cluster disajikan pada Tabel 4.

Sebaran nilai medoid pilar pada tiap cluster disajikan pada Gambar 4. Dapat dilihat bahwa kinerja pilar irigasi pada tiap cluster bervariasi. Cluster 0 memiliki keunggulan pada pilar prasarana dengan nilai paling tinggi di antara cluster lainnya diikuti pilar institusi pengelola. Cluster 1 memiliki keunggulan pada pilar ketersediaan air, diikuti pilar sistem pengelolaan,
Tabel 3. Nilai DBI pada clustering saluran sekunder

\begin{tabular}{cc}
\hline Jumlah cluster & DBI \\
\hline 2 & $-1,101$ \\
3 & $-0,901$ \\
4 & $-1,959$ \\
5 & $-0,822$ \\
6 & $-1,495$ \\
7 & $-0,797$ \\
8 & $-1,062$ \\
9 & $-0,966$ \\
10 & $-0,864$ \\
\hline
\end{tabular}

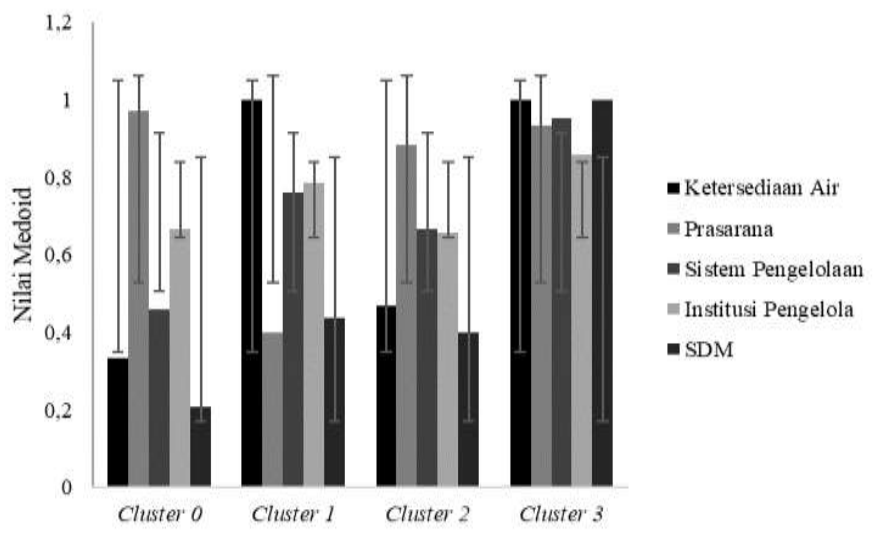

Gambar 4. Sebaran nilai medoid tiap cluster

dan intitusi pengelola. Cluster 2 memiliki keunggulan pada pilar prasarna, diikuti pilar sistem pengelolaan dan institusi pengelola, namun nilainya tidak lebih baik jika dibandingkan dengan cluster 1. Cluster 3 memiliki keunggulan pada kelima pilar.

Terkait dengan penyusunan skala prioritas penanganan cluster, secara visual dapat dikatakan bahwa cluster 3 memiliki kinerja terbaik, sehingga merupakan

Tabel 4. Keanggotaan cluster

\begin{tabular}{ll}
\hline Cluster & Nama saluran sekunder \\
\hline Cluster 0 & $\begin{array}{l}\text { Baledono Hewan, Wongsokrasan, Tegal } \\
\text { Kuning, Tegal Liser, Seboro Krapyak, } \\
\\
\text { Pengen Mangunan }\end{array}$
\end{tabular}

Cluster 1 Sindurjan, Doplang, Tirem, Legundi, Pleret, Bloro Bluduk

Cluster 2 Pabrik Es, Plaosan, Kauman, Koplak, Kenten Grantung, Kenteng Dewi, Korok Alas Tengah, Kesambi Plenden

Cluster 3 Kembar Kleren 
prioritas terakhir dalam penanganan. Akan tetapi untuk ketiga cluster lainnya akan sulit ditentukan urutannya hanya dengan pengamatan nilai medoid secara visual. Untuk itu perlu dilakukan suatu pengambilan keputusan, untuk memperoleh urutan skala prioritas penanganan. Dalam penelitian ini digunakan metode AHP.

\section{Pengambilan Keputusan dengan Metode AHP}

Hasil pengelompokkan kinerja saluran sekunder perlu dianalisis lebih lanjut untuk mengetahui tingkat kepentingan masing-masing cluster dalam hal peningkatan kinerja cluster. Oleh sebab itu, dilakukan penyusunan skala prioritas menggunakan metode AHP. Metode ini merupakan salah satu jenis metode penentuan keputusan yang dapat memudahkan pengguna dalam mengambil keputusan. Dalam penyusunan skala prioritas pengembangan cluster pada tingkat sekunder ini, pertama-tama disusun bagan hierarki yang memuat tujuan, kriteria, dan alternatif. Tujuan yang hendak dicapai adalah memilih cluster dengan kinerja terbaik, kemudian skala prioritas diurutkan dari cluster dengan kinerja terburuk. Kinerja yang dimaksud berkaitan dengan kesiapan menghadapi modernisasi irigasi. Kriteria yang digunakan adalah 5 pilar irigasi, sedangkan alternatifnya adalah cluster 0,1 , 2, dan 3. Bagan hirarki AHP disajikan pada Gambar 5.

Tahap pertama dalam analisis AHP adalah menentukan pairwise comparison kriteria, yaitu berupa matriks yang berisi rasio kepentingan relatif antara kriteria satu dengan kriteria lainnya. Pembuatan matriks pairwise comparison kriteria ini didasarkan pada bobot tiap pilar yang tertuang dalam Pedoman Modernisasi Irigasi. Bobot yang dimaksud adalah $20 \%$ untuk pilar ketersediaan air, 25\% untuk pilar prasaranan, 15\% untuk pilar sistem pengelolaan, 20\% untuk pilar instutusi pengelolaan, dan $20 \%$ untuk pilar sumberdaya manusia (Anonim, 2011). Bobot tersebut kemudian dibandingkan satu sama lain terhadap semua kriteria (pilar), sehingga diperoleh matriks pairwise comparison.

Tahap kedua adalah membuat eigenvector criteria, yaitu dengan mengkuadratkan matriks pairwise comparison kriteria dan menjumlahkan angka dalam satu baris matriks yang diperoleh, kemudian dinormalisasi. Selanjutnya dilakukan iterasi terus menerus hingga tidak ada perubahan pada matriks eigenvector. Tahap ketiga adalah mengkalikan matriks pairwise comparison dengan eigenvector kriteria untuk mendapatkan matriks rangking kriteria. Hasilnya adalah rangking pertama ditempati oleh pilar prasarana dengan nilai bobot 1,25, rangking kedua ditempati oleh 3 pilar yaitu ketersediaan air; institusi pengelola; dan sumberdaya manusia dengan nilai bobot 1,00 , sedangkan rangking ketiga ditempati oleh pilar sistem pengelolaan dengan nilai bobot 0,75 . Hal ini menunjukkan bahwa pilar prasarana paling penting dalam hal peningkatan performa saluran sekunder, sedangkan untuk pilar ketersediaan air; institusi pengelola; dan sumberdaya manusia memiliki tingkat kepentingan yang sama. Pilar sistem pengelolaan paling rendah tingkat kepentingannya dibandingkan dengan pilar-pilar lainnya. Perangkingan kriteria dapat dilihat pada Gambar 6.

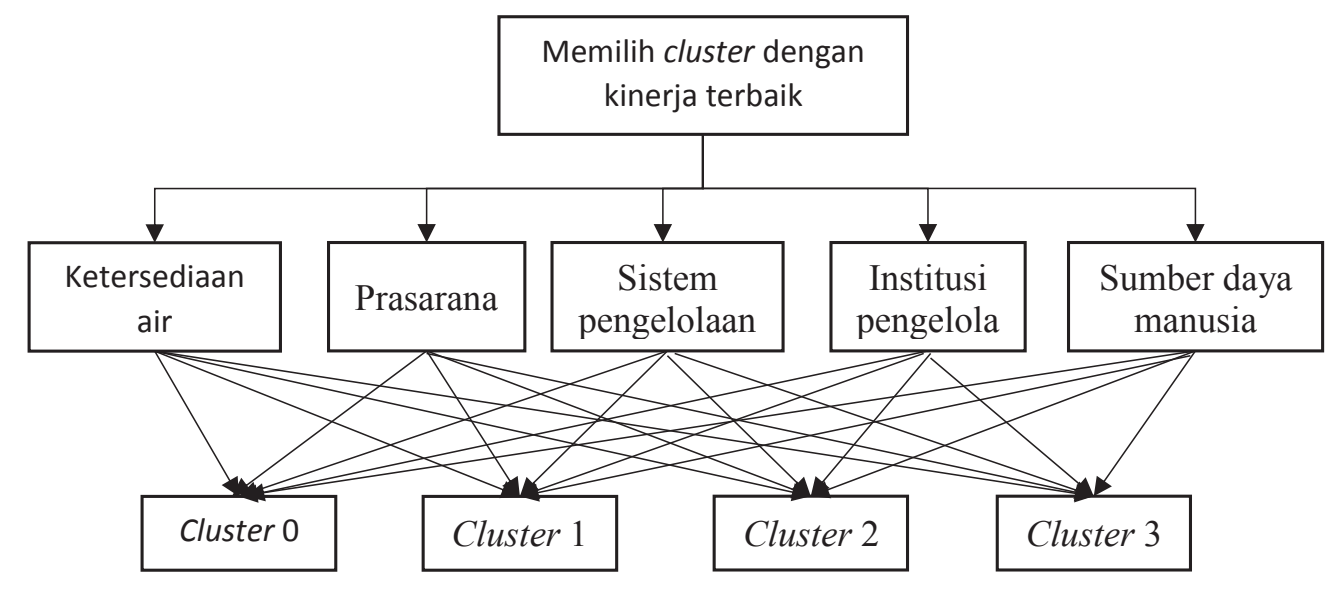

Pairwise comparison kriteria

Eigenvector kriteria
Rangking

kriteria

Gambar 5. Bagan hirarki AHP 
Pairwise comparison kriteria

\begin{tabular}{|c|c|c|c|}
\hline & & $K A$ & $P$ \\
\hline $\mathrm{KA}$ & & 1,00 & 0,80 \\
\hline$P$ & & 1,25 & 1,00 \\
\hline SP & & 0,75 & 0,60 \\
\hline IP & & 1,00 & 0,80 \\
\hline SDM & & 1,00 & 0,80 \\
\hline KA & & \multirow{5}{*}{\multicolumn{2}{|c|}{$\begin{array}{l}\text { ketersediaan air } \\
\text { prasarana } \\
\text { sistem pengelolaan } \\
\text { institusi pengelola } \\
\text { sumberdaya manusi }\end{array}$}} \\
\hline P & & & \\
\hline & . & & \\
\hline & : & & \\
\hline SDM & : & & \\
\hline
\end{tabular}

$\begin{array}{cc}\begin{array}{c}\text { Eigenvector } \\ \text { kriteria }\end{array} & \text { Rangking } \\ \text { kriteria }\end{array}$

$$
\left(\begin{array}{l}
0,20 \\
0,25 \\
0,15 \\
0,20 \\
0,20
\end{array}\right)=\left(\begin{array}{l}
1,00 \\
1,25 \\
0,75 \\
1,00 \\
1,00
\end{array}\right)
$$

Gambar 6. Perangkingan kriteria

Tahap keempat membuat pairwise comparison alternatif terhadap masing-masing kriteria. Dalam hal ini digunakan nilai medoid untuk membandingkan satu sama lain, kemudian dinormalisasi. Tahap terakhir adalah penyusunan matriks solusi dengan cara mengkalikan pairwise comparison alternatif dengan rangking kriteria. Matriks solusi untuk clustering saluran sekunder dapat dilihat pada Gambar 7.

Berdasarkan matriks solusi tersebut diperoleh hasil perangkingan alternatif, dimana rangking 1 merupakan cluster dengan kinerja terbaik, sedangkan rangking 4 adalah cluster dengan kinerja terburuk. Cluster dengan kinerja terbaik berarti siap dilakukan modernisasi, begitu pula sebaliknya. Diperoleh rangking terbaik sampai terendah yaitu cluster 3,1 , 2, dan cluster 0 dengan nilai bobot masing-masing 1,80,1,22, 1,15, dan 1,00. Dalam penyusunan skala prioritas pengembangan saluran sekunder yang tergabung pada cluster, diurutkan dari rangking terendah (rangking 4). Oleh sebab itu skala prioritas pengembangan cluster yang perlu ditingkatkan adalah mengikuti urutan berikut: cluster 0 - cluster 2 cluster 1 - dan terakhir cluster 3.

\section{Rekomendasi Pengembangan}

Setelah disusun suatu skala prioritas dalam rangka penyempurnaan sistem irigasi pada DI Kedung Putri

Pairwise comparison alternatif

\section{Rangking}

kriteria

\begin{tabular}{|c|c|c|c|c|c|c|c|c|c|}
\hline & $\mathrm{KA}$ & $P$ & SP & IP & SDM & \multirow[b]{2}{*}{$*$} & & & \\
\hline Cluster 0 & 0,12 & 0,35 & 0,16 & 0,22 & 0,10 & & $(1,00)$ & \multicolumn{2}{|l|}{ KA } \\
\hline Cluster 1 & 0,36 & 0,14 & 0,27 & 0,26 & 0,21 & & 1,25 & \multicolumn{2}{|l|}{$P$} \\
\hline Cluster 2 & 0,17 & 0,31 & 0,23 & 0,22 & 0,20 & & 0,75 & \multicolumn{2}{|l|}{ SP } \\
\hline Cluster 3 & 0,36 & 0,33 & 0,34 & 0,29 & 0,49 & & 1,00 & \multicolumn{2}{|l|}{ IP } \\
\hline & & & & & & & 1,00 & \multicolumn{2}{|l|}{ SDM } \\
\hline & & & & & & & \multicolumn{3}{|l|}{$\begin{array}{l}\text { Rangking } \\
\text { alternatif }\end{array}$} \\
\hline & & & & & & \multirow{4}{*}{$=$} & $(1,00)$ & 4 & Cluster 0 \\
\hline & & & & & & & 1,22 & 2 & Cluster 1 \\
\hline & & & & & & & 1,15 & 3 & Cluster 2 \\
\hline & & & & & & & 1,80 & 1 & Cluster 3 \\
\hline
\end{tabular}

Gambar 7. Matriks solusi 
Tabel 5 Pemetaan kondisi pilar pada clustering tingkat sekunder

\begin{tabular}{cccccc}
\hline \multirow{2}{*}{$\begin{array}{c}\text { Urutan } \\
\text { skala } \\
\text { prioritas }\end{array}$} & $\begin{array}{c}\text { Ketersediaan } \\
\text { air }\end{array}$ & Prasarana & $\begin{array}{c}\text { Sistem } \\
\text { pengelolaan }\end{array}$ & $\begin{array}{c}\text { Institusi } \\
\text { pengelola }\end{array}$ & $\begin{array}{c}\text { Sumberdaya } \\
\text { manusia }\end{array}$ \\
\cline { 2 - 6 } Cluster 0 & kurang & baik & kurang & cukup & Sangat kurang \\
Cluster 2 & kurang & baik & cukup & cukup & kurang \\
Cluster 1 & baik & kurang & cukup & cukup & kurang \\
Cluster 3 & baik & baik & baik & baik & baik \\
\hline
\end{tabular}

tingkat sekunder, maka perlu disusun suatu rencana perbaikan tiap pilar pada cluster. Rencana tersebut disusun berdasarkan kondisi tiap pilar pada masingmasing cluster yang direpresentasikan oleh nilai medoid. Nilai medoid disesuaikan dengan kategori penilaian modernisasi irigasi, sehingga diperoleh pemetaan kondisi pilar pada tiap cluster. Kondisi tiap pilar irigasi inilah yang digunakan sebagai dasar dalam merumuskan rekomendasi rencana perbaikan atau pengembangan cluster pada tingkat sekunder. Berdasarkan nilai medoid dan skala prioritas dari AHP, diperoleh pemetaan kondisi pilar masing-masing cluster seperti pada Tabel 5.

Berdasarkan pemetaan pada Tabel 5, secara visual tampak bahwa cluster 0 memiliki kinerja paling buruk sebaliknya cluster 3 memiliki kinerja paling baik. Cluster 2 dan 1 memiliki gambaran kondisi yang hampir sama, hanya berbeda pada kondisi pilar ketersediaan air dan prasarana. Cluster 2 kurang pada pilar ketersediaan air dan baik pada prasarana, sebaliknya cluster 1 baik pada pilar ketersediaan air dan kurang pada pilar prasarana. Pilar prasarana memiliki bobot paling tinggi dibanding pilar lainnya, sehingga kemungkinan secara visual akan dikatakan bahwa cluster 2 lebih baik daripada cluster 1. Oleh sebab itu, perlu dilakukan analisis dengan metode AHP yang memperhitungkan setiap nilai dan bobot pilar dan cluster, sehingga dalam penentuan skala prioritas lebih obyektif dan tepat.

Berdasarkan analisis AHP, cluster 1 lebih baik daripada cluster 2, sehingga dalam rencana pengembangan lebih diprioritaskan cluster 2. Akan tetapi dalam implementasinya, pengembangan kedua cluster ini justru dapat dilakukaan secara bersamaan, sehingga akan lebih efisien dari segi waktu, biaya, maupun tenaga. Rencana pengembangan pada tingkat sekunder dimulai dari cluster 0, 2, dan 1 . Cluster 3 memiliki kinerja baik pada seluruh pilar irigasi, sehingga hanya perlu perbaikan minor terutama untuk pilar prasarana, misalnya saja dengan mempertahankan pola operasi dan pemeliharaan yang ada. Matriks rekomendasi pada setiap cluster pada tingkat sekunder dapat dilihat pada Tabel 6.

\section{KESIMPULAN}

Berdasarkan penilaian kesiapan modernisasi irigasi, secara keseluruhan DI Kedung Putri pada tingkat sekunder belum siap untuk dimodernisasi. Untuk itu diperlukan suatu rencana perbaikan dan penyerpurnaan sistem terlebih dahulu. Rencana tersebut lebih efisien jika dilakukan secara berkelompok, yaitu dengan mengelompokkan saluran sekunder berdasarkan

Tabel 6. Matriks rekomendasi rencana pengembangan pilar pada clustering tingkat sekunder

\begin{tabular}{|c|c|c|c|c|c|}
\hline \multirow{2}{*}{$\begin{array}{c}\text { Urutan } \\
\text { skala } \\
\text { prioritas }\end{array}$} & \multicolumn{5}{|c|}{ Pilar irigasi } \\
\hline & Ketersediaan air & Prasarana & Sistem pengelolaan & Institusi pengelola & $\begin{array}{c}\text { Sumberdaya } \\
\text { manusia }\end{array}$ \\
\hline Cluster 0 & Peningkatan pasokan air & Pemeliharaan rutin & Pendampingan teknis & Penguatan institusi & Kampanye publik \\
\hline Cluster 2 & Peningkatan pasokan air & Pemeliharaan rutin & Pendampingan teknis & Penguatan institusi & Kampanye publik \\
\hline Cluster 1 & Pemeliharaan rutin saluran & Pemeliharaan berkala & Pendampingan teknis & Penguatan institusi & Kampanye publik \\
\hline Cluster 3 & Pemeliharaan rutin saluran & Pemeliharaan rutin & - & - & - \\
\hline
\end{tabular}


kemiripan kinerja pilar irigasi, atau disebut dengan clustering. Metode clustering yang digunakan adalah k-medoids, dengan menggunakan tool berupa software Rapid Miner 9.0. Diperoleh jumlah cluster yang paling optimal adalah 4 (cluster 0, 1, 2, dan 3), yang ditunjukkan dengan nilai DBI -1,959. Pengambilan keputusan disusun menggunakan metode AHP. Hasil menunjukkan bahwa rencana penanganan dimulai dari saluran sekunder yang tergabung pada cluster 0 , diikuti dengan cluster 2 dan 1 . Cluster 3 memiliki kinerja baik pada seluruh pilar, sehingga hanya perlu mempertahankan pola operasi dan pemeliharaan yang ada.

\section{UCAPAN TERIMA KASIH}

Ucapan terima kasih disampaikan kepada BPUSDATARU Probolo dan Unit Pelaksana Teknis (UPT) Wilayah Purworejo yang telah memfasilitasi pengambilan data penelitian, serta membantu dalam keseluruhan rangkaian kegiatan. Ucapan terima kasih juga disampaikan kepada perwakilan anggota P3A selaku responden dalam pengambilan data. Penghargaan juga disampaikan kepada BPPTNBH dan Direktorat Penelitian UGM yang menyediakan dana penelitian, dalam skema hibah peningkatan kapasitas peneliti dosen muda. Ucapan terima kasih kepada Ibu Dr. Murtiningrum dan Dr. Ngadisih atas segala masukan yang telah diberikan

\section{KONFLIK KEPENTINGAN}

Dengan ini penulis menyatakan bahwa artikel ini asli, belum pernah dipublikasikan, dan bebas dari konflik kepentingan.

\section{DAFTAR PUSTAKA}

Adiana, B. E., Soesanti, I., \& Permanasari, A. E. (2018). Analisis Segmentasi Pelanggan Menggunakan Kombinasi RFM Model dan Teknik Clustering. JUTEI, 2(1), 23-32. https://doi.org/10.21460/jutei.2017.21.76.

Anonim. (2011). Pedoman Modernisasi Irigasi. Direktorat Irigasi dan Rawa Jakarta.

Bhat, A. (2014). K-Medoids Clustering Using Partitioning Around Medoids For Performing Face Recognition. International Journal of Soft Computing, Mathematics and Control, 3(3), 1-12. https://doi.org/10.14810/ ijscmc. 2014.3301.
Haas, R., \& Meixner, O. (2005). An Illustrated Guide to The Analytic Hierarchy Process. Vienna: University of Natural Resources and Applied Life Science.

Han, J., Kamber, M., \& Pei, J. (2001). Data Mining - Consepts and Techniques. USA: Morgan Kaufman.

Hardiani, T., Selo, S., \& Hartanto, R. (2017). Segmentasi Nasabah Tabungan Menggunakan Model RFM (Recency , Frequency, Monetary) dan K-Means Pada Lembaga Keuangan Mikro. In Seminar Nasional Teknologi Informasi dan Komunikasi Terapan.

Jain, Y. K., \& Bhandare, S. K. (2011). Min Max Normalization Based Data Perturbation Method for Privacy Protection. International Journal of Computer \& Communication Technology, 2(VIII), 45-50.

Kaur, N. K., Kaur, U., \& Singh, D. (2014). K-Medoid Clustering Algorithm- A Review. International Journal of Computer Application and Technology, 1(1), 42-45.

Mulyadi, Soekarno, I., \& Winskayati. (2014). Analisis Pilar Modernisasi Irigasi dengan Pendekatan Analytical Hierarchy Process ( AHP ) pada Daerah Irigasi Barugbug - Jawa Barat. Jurnal Teoretis Dan Terapan Bidang Rekayasa Sipil, 21(3), 213-220.

Murtiningrum, Masithoh, R. E., \& Jatmiko, M. W. (2007). Optimalisasi Penggunaan Pompa Dalam Sistem Irigasi Dengan Metode Analytical Hierarchy Process di Daerah Irigasi Pacal Kabupaten Bojonegoro. Agritech, 27(2), 48-58. https://doi.org/10.22146/agritech.9493

Nugraha, R. F. (2018). Pengelompokan dan Pemetaan Perkumpulan Petani Pemakai Air (P3A) Daerah Irigasi Kedung Serayu Berdasarkan Nilai Indeks Kesiapan Modernisasi Irigasi (IKMI) dengan Analisis Fuzzy C-Means (FCM). Universitas Gadah Mada.

Pramesti, D. F., Furqon, M. T., \& Dewi, C. (2017). Implementasi Metode K-Medoids Clustering Untuk Pengelompokan Data Potensi Kebakaran Hutan / Lahan Berdasarkan Persebaran Titik Panas ( Hotspot ). Jurnal Pengembangan Teknologi Informasi dan Ilmu Komputer, 1(9), 723-732.

Saaty, T. L. (2008). Decision making with the analytic hierarchy process. International Journal Services Sciences, 1(1). https://doi.org/10.1504/IJSSci.2008.01759

Soni, K. G., \& Patel, A. (2017). Comparative Analysis of K-means and K-medoids Algorithm on IRIS Data. International Journal of Computational Intelligence Research, 13(5), 899-906. 